\title{
A STABILITY INDICATING ION-PAIR LC METHOD FOR THE DETERMINATION OF ASENAPINE IN PHARMACEUTICALS
}

\author{
SAKINE ATILA KARACA, DUYGU YENICELI UĞUR* \\ Anadolu University, Faculty of Pharmacy, Department of Analytical Chemistry, 26470 Eskisehir, Turkey
}

\begin{abstract}
In this study, a new, simple and specific stability indicating ion-pair LC method was developed and fully validated for the determination of asenapine in tablets. The analysis was performed on an Agilent Eclipse XDB-C8 column $\left(4.6 \times 150 \mathrm{~mm}, 3.5 \mu \mathrm{m}\right.$ particles) at $30^{\circ} \mathrm{C}$. A mixture of phosphate buffer (pH 3,20 $\mathrm{mM}$ ) containing $10 \mathrm{mM}$ 1-heptane sulfonic acid and acetonitrile, $(60: 40, \mathrm{v} / \mathrm{v})$ at a flow rate of $1 \mathrm{~mL} \mathrm{~min}{ }^{-1}$ was used as mobile phase. Detection was performed by a diode array detector at $220 \mathrm{~nm}$. The developed method was validated according to related ICH guideline and US Pharmacopeia and it was suitable in terms of accuracy, precision, specificity, robustness and stability. The method was linear in the concentration range of $0.5-100 \mu \mathrm{g} \mathrm{mL} L^{-1}$. Limit of detection and limit of quantification values were calculated as $0.0836 \mu \mathrm{g} \mathrm{mL}^{-1}$ and $0.2788 \mu \mathrm{g} \mathrm{mL} \mathrm{m}^{-1}$, respectively. This ion-pair LC method was applied successfully for the determination of asenapine in its sublingual tablets.
\end{abstract}

Keywords: asenapine, HPLC, ion-pair chromatography, tablet analysis

\section{INTRODUCTION}

The antipsychotics are a group of drugs that are used for the treatment of schizophrenia and other psychotic disorders ${ }^{1}$. Asenapine (ASE) is an atypical antipsychotic agent used in the treatment of schizophrenia, affecting its positive symptoms (auditory hallucinations, disorganized thoughts and delusions), negative symptoms (social withdrawal, lack of motivation) and cognitive dysfunction (disorganized thinking, memory impairments). It is also effective in treating bipolar disorder during manic and mixed episodes. ASE has been commercially available in sublingual tablet form in USA since 2009 and in Europe since $2010^{2-4}$.

ASE, (Figure 1), (3aRS,12bRS)-5-Chloro-2-methyl-2,3,3a,12b-tetrahydro$1 \mathrm{H}$-dibenzo[ 2,3:6,7] oxepino[4,5-c]pyrrole (2Z)-2-butenedioate $(1: 1)^{5}$, has a different receptor interaction profile compared to other antipsychotics. It has affinity on serotonin receptors $\left(5-\mathrm{HT}_{1 \mathrm{~A}}, 5-\mathrm{HT}_{1 \mathrm{~B}}, 5-\mathrm{HT} 2 \mathrm{~A}, 5-\mathrm{HT}_{2 \mathrm{~B}}, 5-\mathrm{HT}_{2 \mathrm{C}}\right.$, $5-\mathrm{HT}_{5}, 5-\mathrm{HT}_{6}$ and 5- $\left.\mathrm{HT}_{7}\right)$, dopamine receptors $\left(\mathrm{D}_{1}, \mathrm{D}_{2}, \mathrm{D}_{3}\right.$ and $\left.\mathrm{D}_{4}\right)$, adrenergic receptors $\left(\alpha_{1}\right.$ and $\left.\alpha_{2}\right)$, histamine $\left(\mathrm{H}_{1}\right)$ receptors and also moderate affinity on histamine $\left(\mathrm{H}_{2}\right)$ receptors. ASE has antagonistic effect on all these receptors ${ }^{6}$.

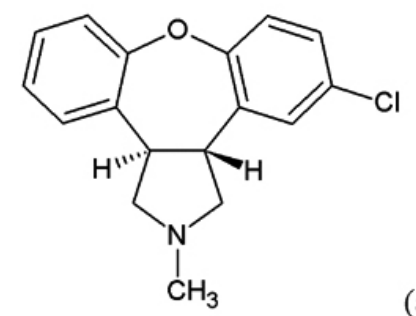

(a)

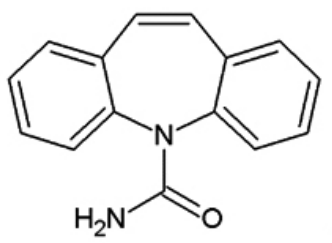

(b)

Figure 1. Chemical structures of ASE (a) and IS (b)

ASE, formulated as sublingual tablets, is highly metabolized after oral administration. It has approximately 38 metabolites which are not clinically effective. Its peak plasma concentration $\left(\mathrm{C}_{\max }\right)$ is $4 \mathrm{ng} \mathrm{mL}^{-1}$ and the time to reach this concentration $\left(\mathrm{T}_{\text {max }}\right)$ is about 1 hour. ASE is extensively bound to serum proteins with a binding rate of $95 \%{ }^{7}$.

In the literature, the methods were mostly developed for the analysis of ASE in different biological fluids (serum, plasma, whole blood, urine, hair and nail samples). These methods include liquid chromatography ${ }^{8}$, liquid chromatography-mass spectrometry ${ }^{9-14}$ and gas chromatography-mass spectrometry ${ }^{15}$

There are limited number of methods that aim to determine ASE in bulk and pharmaceutical dosage forms. These methods are titrimetry ${ }^{16}$, UV spectrometry ${ }^{17}$, HPLC ${ }^{18-19}$ and HPTLC methods ${ }^{20}$. Most of these methods are lack of enough specificity and sensitivity with narrow concentration ranges ${ }^{16-}$
${ }^{17}$. Chhalotiya et al. ${ }^{19}$ developed the only stability indicating HPLC method for ASE analysis in bulk and pharmaceutical formulations whereas other HPLC method doesn't include even any data about the stability of the analyte ${ }^{18}$. The proposed method has several advantages over these HPLC methods like better quantification using an internal standard (IS), better peak efficiency (theoretical plate number of 12040, instead of 3805 and 5061) and high upper limit of linearity range.

In this study, the aim is to develop a new, simple and sensitive fully validated stability indicating HPLC method for the determination of ASE in its tablets.

\section{EXPERIMENTAL}

Material and Reagents

ASE maleat and carbamazepine (CBZ) were purchased from Sigma Aldrich (India). All solvents used in this study were of HPLC grade (Sigma Aldrich, Germany). Hydrochloric acid was obtained from Sigma Aldrich (Germany). Sodium hydroxide, hydrogen peroxide, 1-heptane sulfonic acid, phosphoric acid and potassium dihydrogen phosphate were purchased from Merck (Germany). Sycrest $10 \mathrm{mg}$ sublingual tablets (MSD) were obtained from Lundbeck (Germany).

Instrumentation and Chromatographic Conditions

A HPLC system (Agilent 1290 Infinity, Germany) consisted of a binary pump, a degasser, an auto sampler, a thermostated column compartment and a diode array detector was employed for this study. Separation was performed on an Agilent Eclipse XDB-C 8 column $\left(4.6 \times 150 \mathrm{~mm}, 3.5 \mu \mathrm{m}\right.$ particles) at $30^{\circ}$ C. A mixture of phosphate buffer ( $\mathrm{pH} \mathrm{3,20} \mathrm{mM)} \mathrm{containing} 10 \mathrm{mM}$ 1-heptane sulfonic acid and acetonitrile $(60: 40, \mathrm{v} / \mathrm{v})$ was used as mobile phase at a flow rate of $1 \mathrm{~mL} \mathrm{~min}{ }^{-1}$. Injection volume was set at $5 \mu \mathrm{L}$ and ASE was detected at $220 \mathrm{~nm}$.

\section{Preparation of Standard Solutions}

A stock solution of ASE $\left(1 \mathrm{mg} \mathrm{mL}^{-1}\right)$ was prepared in methanol and serially diluted with methanol to obtain working standard solutions in the concentration range of $0.5-100 \mu \mathrm{g} \mathrm{mL}^{-1}$. An IS solution of CBZ $\left(1.28 \mathrm{mg} \mathrm{mL}^{-1}\right)$ was prepared in methanol and used at a fixed concentration of $16 \mu \mathrm{g} \mathrm{mL}^{-1}$. Stock solutions and standards were kept at $4{ }^{\circ} \mathrm{C}$.

Method Validation

The proposed method was validated according to ICH guideline and USP ${ }^{21-22}$ by evaluating the parameters of linearity, limit of detection (LOD) and limit of quantification (LOQ), accuracy and precision, stability, specificity and robustness. Calculations were performed using GraphPad Prism 6 and Microsoft Excel softwares.

Working standard solutions of ASE were prepared in the range of 0.5-100 $\mu \mathrm{g} \mathrm{mL}-1$ for three days and linearity was evaluated by linear regression analysis using the least squares regression method.

Three different solutions of ASE $\left(0.5,10\right.$ and $\left.100 \mu \mathrm{g} \mathrm{mL}^{-1}\right)$ were prepared and analyzed in seven independent series on the same day and on three consecutive days to evaluate the precision of the method as repeatability (intra- 
day) and intermediate precision (inter-day).

The accuracy of the method was determined by analysis both quality control samples prepared using a standard ASE solution and a solution of synthetic inactive ingredients (matrix) spiked with different known concentrations of ASE (within the calibration range). The matrix solution was prepared in methanol using common tablet excipients such as hydroxypropyl methyl cellulose $(8 \%)$, lactose monohydrate $(71 \%)$, magnesium stearate $(1$ $\%)$, polyethylene glycol $4000(6 \%)$, povidone $(6 \%)$, maize starch $(6 \%)$, talc $(1 \%)$, titanium dioxide (1\%). Standard ASE solutions were prepared at three concentrations $\left(0.5,10\right.$ and $\left.100 \mu \mathrm{g} \mathrm{mL}^{-1}\right)$ in methanol and in matrix solution. Percentage recovery, percentage error and percentage RSD values were determined.

ASE solutions $\left(25 \mu \mathrm{g} \mathrm{mL}^{-1}\right)$ were subjected to stress by treatment with 0.1 $\mathrm{M} \mathrm{HCl}, 0.1 \mathrm{M} \mathrm{NaOH}$ and $3 \% \mathrm{H}_{2} \mathrm{O}_{2}$ at both room temperature and $60^{\circ} \mathrm{C}$ for different times $(15,30,45,60,90$ and $120 \mathrm{~min})$ and analyzed to evaluate the specificity of the method. The samples were injected for HPLC analysis after dilution to $5 \mu \mathrm{g} \mathrm{mL}^{-1}$.

The robustness of the method was studied in triplicate for a concentration of $10 \mu \mathrm{g} \mathrm{mL}^{-1}$, by making deliberate modifications in $\mathrm{pH}$ value, percentage of organic phase, buffer concentration, ion pair reagent concentration, detection wavelength and mobile phase flow rate. The effect of these changes on the results was examined and the system-suitability data for ASE were calculated for each variation.

The stability of standard solutions of ASE was evaluated under different conditions by triplicate analysis of solutions at two concentrations, 10 and $100 \mu \mathrm{g} \mathrm{mL}^{-1}$. For short-term stability, standard solutions of ASE were stored at room temperature for $24 \mathrm{~h}$. Long-term stability was assessed after storage of the solutions in a freezer at $-20^{\circ} \mathrm{C}$ for 2 weeks. To test freeze and thaw stability, ASE solutions were stored at $-20^{\circ} \mathrm{C}$ for $24 \mathrm{~h}$ and thawed to room temperature three times and then analyzed.

Sample Preparation

Sycrest ${ }^{\mathbb{B}}$ sublingual tablets (each containing $10 \mathrm{mg}$ ASE) were weighed and powdered in a mortar. Methanol was added to a tablet content to dissolve the active material and it was sonicated for $10 \mathrm{~min}$. Then, the solution was centrifuged at $5000 \mathrm{rpm}$ for $10 \mathrm{~min}$ and the supernatant was diluted to obtain the concentrations in the available range of calibration studies.

\section{RESULTS AND DISCUSSION}

\section{Method Optimization}

An ASE solution at a concentration of $50 \mu \mathrm{g} \mathrm{mL}^{-1}$ was used during optimization studies and injection volume was set at $5 \mu \mathrm{L}$. Initial separations were performed on an Agilent Zorbax Eclipse Plus C18 column (4.6 x 100 $\mathrm{mm}, 3.5 \mu \mathrm{m}$ particles). Mixtures that contain water, acetonitrile and methanol at different proportions were tested as mobile phase and a mixture of water and acetonitrile $(60: 40, \mathrm{v} / \mathrm{v})$ was selected. For keeping the $\mathrm{pH}$ value of mobile phase stable and improving peak morphology, phosphate and acetate buffers were tested as mobile phase additives at different $\mathrm{pH}$ values $(\mathrm{pH} 3,4,5$ and 6). Phosphate buffer ( $\mathrm{pH} 3$ ) was selected as an optimum buffer considering suitable retention time of ASE and the best results for system-suitability parameters (Figure 2). Analyzes were performed with mobile phases that contain phosphate buffer ( $\mathrm{pH} 3)$ at different concentrations $(10 \mathrm{mM}, 15 \mathrm{mM}, 20$ $\mathrm{mM}$ and $25 \mathrm{mM}$ ). The theoretical plate of ASE peak increased with the increase of buffer concentration (Figure 3). The use of excessive buffer concentrations was avoided and $20 \mathrm{mM}$ was chosen as an optimum buffer concentration to assure the stability of the column, and to minimize the cost of analysis.

Even after all these modifications on mobile phase, desired peak shape couldn't be obtained, therefore the ion-pair chromatography was used. For this purpose a column previously used in ion-pair chromatography was equipped to HPLC system and separations were performed on this Agilent Eclipse XDB-C8 column ( $4.6 \times 150 \mathrm{~mm}, 3.5 \mu \mathrm{m}$ particles). 1-heptane sulfonic acid (HSA) was chosen as ion-pair agent and added to mobile phase at different concentrations $(5 \mathrm{mM}, 10 \mathrm{mM}$ and $20 \mathrm{mM})$. The best peak shape and systemsuitability parameters were observed with the mobile phase containing $10 \mathrm{mM}$ HSA. Therefore a mixture of phosphate buffer $(\mathrm{pH} \mathrm{3,20} \mathrm{mM)} \mathrm{containing} 10$ mM HSA and acetonitrile was used as mobile phase $(60: 40, \mathrm{v} / \mathrm{v})$. Changes at column temperature didn't make a significant difference, so column temperature was set at $30^{\circ} \mathrm{C}$. $220 \mathrm{~nm}$ was chosen as detection wavelength because of high absorbance at this wavelength.

Chlorpromazine, carbamazepine (CBZ), bupropion and atomoxetine were tested as IS. CBZ was selected due to its retention time which is close to ASE and appropriate system-suitability parameters at optimized conditions. A chromatogram of ASE $\left(50 \mu \mathrm{g} \mathrm{mL}^{-1}\right)$ and $\mathrm{CBZ}(16 \mu \mathrm{g} \mathrm{mL}-1)$ at these optimum conditions is given in Figure 4.

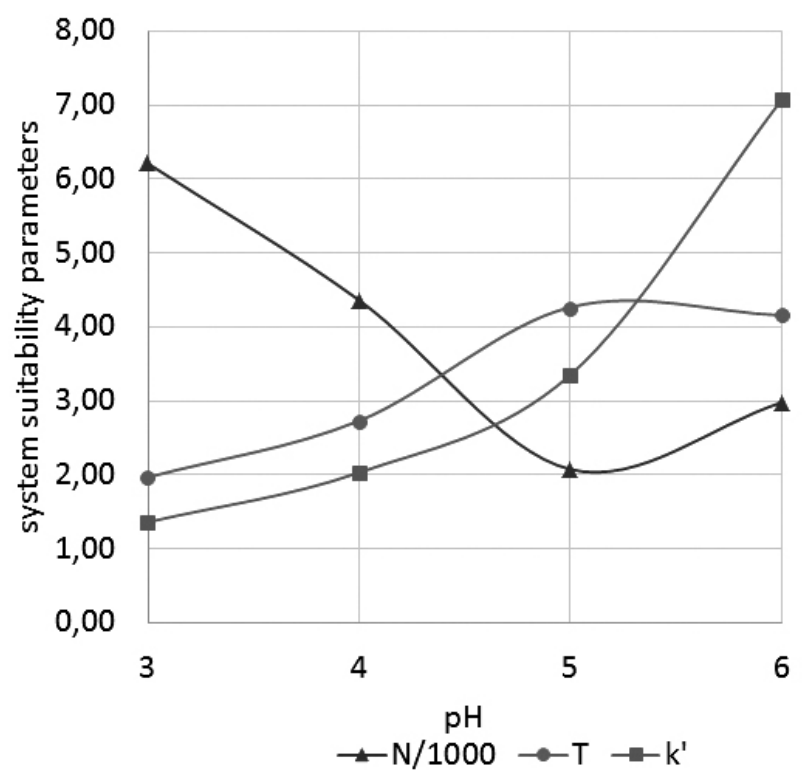

Figure 2. The effect of $\mathrm{pH}$ on system-suitability parameters.

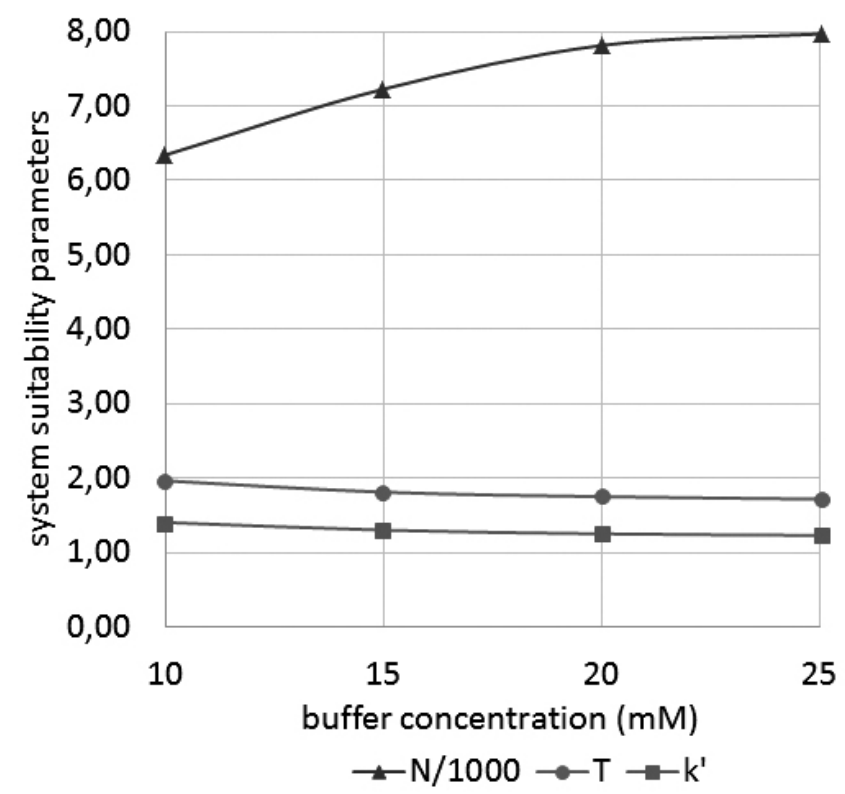

Figure 3. The effect of buffer concentration on system-suitability parameters.

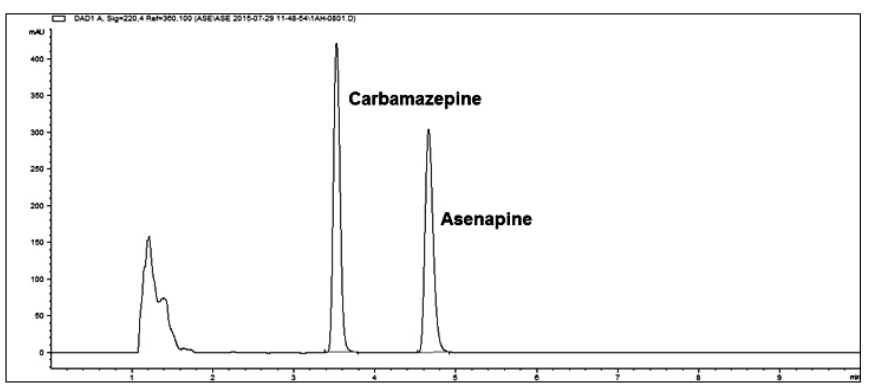

Figure 4. Chromatogram of $\mathrm{ASE}\left(50 \mu \mathrm{g} \mathrm{mL}^{-1}\right)$ and $\mathrm{CBZ}(16 \mu \mathrm{g} \mathrm{mL}-1)$ at optimum conditions. 
Using these optimized conditions, the system-suitability data for ASE $\left(10 \mu \mathrm{g} \mathrm{mL} \mathrm{L}^{-1}\right)$ are presented in Table 1 . Good agreement was found when the results were compared with the recommended values ${ }^{23}$.

Table 1. System-suitability data for ASE.

\begin{tabular}{|c|c|c|}
\hline Parameters & Obtained values & Recommended values \\
\hline Retention time & 4.71 & - \\
\hline Capacity factor ( $\left.\mathrm{k}^{\prime}\right)$ & 2.15 & $>2$ \\
\hline Tailing factor $(\mathrm{T})$ & 1.20 & $\leq 2$ \\
\hline Resolution (Rs) & 7.46 & $>2$ \\
\hline Theoretical plates $(\mathrm{N})$ & 12040 & $>2000$ \\
\hline RSD (\%) of retention time $(\mathrm{n}=7)$ & 0.03 & $\leq 1$ \\
\hline
\end{tabular}

Method Validation

Linearity of the method was investigated by analyzing three sets of calibration solutions ( $\mathrm{n}=7$ ) in the range of 0.5 to $100 \mu \mathrm{g} \mathrm{mL} \mathrm{m}^{-1}$. Calibration curves were constructed using the peak area ratio of ASE to that of the IS, and applying a linear regression analysis. Good linear response was obtained over this concentration range for ASE as seen in Table 2.

Table 2. Statistical data for the linearity of ASE.

\begin{tabular}{|l|c|c|c|c|}
\hline \multirow{2}{*}{ Parameters } & \multicolumn{3}{|c|}{ Intraday $(\mathbf{n = 7})$} & Inter day $(\mathbf{n}=\mathbf{2 1})$ \\
\cline { 2 - 5 } & Day 1 & Day 2 & Day 3 & Whole days \\
\hline Slope \pm SD & $0.0148 \pm 0.0002$ & $0.0176 \pm 8.8 \mathrm{E}-6$ & $0.0209 \pm 0.0002$ & $0.0176 \pm 8.4 \mathrm{E}-5$ \\
\hline Intercept \pm SD & $0.0096 \pm 0.0087$ & $0.0004 \pm 0.0004$ & $0.0052 \pm 0.0098$ & $-0.0012 \pm 0.0023$ \\
\hline Determination Coefficient $\left(\mathrm{r}^{2}\right)$ & 0.9991 & 1.000 & 0.9994 & 0.9996 \\
\hline $95 \%$ Confidence Limits $(\mathrm{CL})$ & $0.0142-0.0153$ & $0.0175-0.0176$ & $0.0203-0.0215$ & $0.0173-0.0177$ \\
\hline
\end{tabular}

The accuracy of the method was evaluated as percentage relative error [((found concentration-spiked concentration)/spiked concentration) $\mathrm{x} 100 \%$ ], and precision was evaluated by determination of the coefficient of variation (CV \%, RSD \%, [SD/mean x 100]) at low, central and high concentrations in the linearity range. The acceptance criteria are no higher than $2 \%$ deviation from the nominal value for accuracy and no more than $2 \%$ RSD for precision ${ }^{24}$. Recovery was in the range of $98-101 \%$ for the drug substance and the drug product, and accuracy was much better than the acceptance criterion (Table 3-4). The RSD values were also much better than the acceptance criterion, showing the precision of the method was good.

Table 3. Precision and accuracy of ASE.

\begin{tabular}{|c|c|c|c|c|}
\hline \multirow{2}{*}{$\begin{array}{l}\text { Parameter } \\
\left(0.5 \mu \mathrm{g} \mathrm{mL} \mathbf{L}^{-1}\right)\end{array}$} & \multicolumn{3}{|c|}{ Intraday $(n=7)$} & \multirow{2}{*}{$\begin{array}{c}\text { Inter day }(\mathrm{n}=\mathbf{2 1}) \\
\text { Whole days } \\
\end{array}$} \\
\hline & Day 1 & Day 2 & Day 3 & \\
\hline \multirow{2}{*}{ Measured Concentration $(\operatorname{mean} \pm \mathrm{SD})\left(\mu \mathrm{g} \mathrm{mL} \mathrm{m}^{-1}\right)$} & $0.4967 \pm$ & $0.4965 \pm$ & $0.4955 \pm$ & $0.4962 \pm$ \\
\hline & 0.0013 & 0.0009 & 0.0015 & 0.0013 \\
\hline RSD (\%) & 0.27 & 0.17 & 0.29 & 0.26 \\
\hline Recovery (\%) & 99.35 & 99.30 & 99.09 & 99.25 \\
\hline Accuracy (\%) & -0.65 & -0.70 & -0.91 & -0.75 \\
\hline \multirow{2}{*}{$\begin{array}{l}\text { Parameter } \\
\left(10 \mu g \mathbf{m L}^{-1}\right)\end{array}$} & \multicolumn{3}{|c|}{ Intraday } & Inter day \\
\hline & Day 1 & Day 2 & Day 3 & Whole days \\
\hline Measured Concentration $(\operatorname{mean} \pm \mathrm{SD})\left(\mu \mathrm{g} \mathrm{mL}^{-1}\right)$ & $9.9733 \pm 0.0431$ & $9.9737 \pm 0.0370$ & $9.9889 \pm 0.0104$ & $9.9786 \pm 0.0325$ \\
\hline RSD (\%) & 0.43 & 0.37 & 0.10 & 0.32 \\
\hline Recovery (\%) & 99.73 & 99.74 & 99.89 & 99.79 \\
\hline Accuracy $(\%)$ & -0.27 & -0.26 & -0.11 & -0.21 \\
\hline \multirow{2}{*}{$\begin{array}{l}\text { Parameter } \\
\left(100 \mu \mathrm{g} \mathbf{m L}^{-1}\right)\end{array}$} & \multicolumn{3}{|c|}{ Intraday } & Inter day \\
\hline & Day 1 & Day 2 & Day 3 & Whole days \\
\hline Measured Concentration $(\operatorname{mean} \pm \mathrm{SD})\left(\mu \mathrm{g} \mathrm{mL}^{-1}\right)$ & $100.7371 \pm 0.1826$ & $100.2971 \pm 0.2437$ & $100.2264 \pm 0.2464$ & $100.4202 \pm 0.3156$ \\
\hline RSD (\%) & 0.18 & 0.24 & 0.24 & 0.31 \\
\hline Recovery (\%) & 100.74 & 100.30 & 100.23 & 100.42 \\
\hline Accuracy $(\%)$ & 0.74 & 0.30 & 0.23 & 0.42 \\
\hline
\end{tabular}


Table 4. Accuracy of ASE in matrix solution

\begin{tabular}{|c|c|c|c|c|}
\hline $\begin{array}{c}\text { Added Concentration } \\
\left(\mu \mathrm{g} \mathbf{~ m L}^{-1}\right)\end{array}$ & $\begin{array}{c}\text { Measured Concentration } \\
(\mathbf{m e a n} \pm \mathbf{S D})\left(\mu \mathrm{g} \mathbf{~ m L}^{-1}\right)\end{array}$ & RSD (\%) & $\begin{array}{c}\text { Recovery } \\
(\%)\end{array}$ & $\begin{array}{c}\text { Accuracy } \\
(\%)\end{array}$ \\
\hline 0.5 & $0.4897 \pm 0.0024$ & 0.48 & 97.94 & -2.06 \\
\hline 10 & $10.0939 \pm 0.0174$ & 0.17 & 100.94 & 0.94 \\
\hline 100 & $100.44107 \pm 0.1232$ & 0.12 & 100.44 & 0.44 \\
\hline
\end{tabular}

The specificity of the method was determined by analysis of ASE solutions that were stored under different stress conditions. $25 \mu \mathrm{g} \mathrm{mL}{ }^{-1} \mathrm{ASE}$ solutions were subjected to stress by treatment with $0.1 \mathrm{M} \mathrm{HCl}, 0.1 \mathrm{M} \mathrm{NaOH}$ and $3 \% \mathrm{H}_{2} \mathrm{O}_{2}$ at both room temperature and $60^{\circ} \mathrm{C}$. Samples were collected at different times $(0,15$, $30,45,60,90$ and 120 minutes) and analyzed. Recovery (\%) values of the samples collected after 120 minutes are given at Table 5. No degradation peak which could interfere with ASE peak was observed, showing the specificity of the method.

Table 5. Recovery of ASE under different stress conditions

\begin{tabular}{|c|c|c|}
\hline Conditions & $\begin{array}{c}\text { Recovery }(\%) \\
\text { (room temperature) }\end{array}$ & $\begin{array}{c}\text { Recovery }(\%) \\
\left(60^{\circ} \mathrm{C}\right)\end{array}$ \\
\hline $\mathrm{NaOH}(0.1 \mathrm{~N})$ & 86.65 & 72.35 \\
\hline $\mathrm{HCl}(0.1 \mathrm{~N})$ & 93.73 & 106.00 \\
\hline $\mathrm{H}_{2} \mathrm{O}_{2}(3 \%)$ & 94.28 & 80.55 \\
\hline
\end{tabular}

The stability studies were performed by analyzing ASE solutions after keeping them under different storage conditions. In all conditions recovery (\%) values were in the range of $92-113 \%$ and low RSD values were obtained as seen in Table 6. ASE standard solutions were therefore stable under all the conditions tested.

Table 6. The stability of ASE under different storage conditions.

\begin{tabular}{|c|c|c|c|c|c|c|}
\hline \multirow{2}{*}{$\begin{array}{l}\text { Added Concentration } \\
\qquad\left(\mu \mathrm{g} \mathbf{~ m L}^{-1}\right)\end{array}$} & \multicolumn{2}{|c|}{$\begin{array}{c}\text { Short-term stability ( } 24 \mathrm{~h} \text {, room } \\
\text { temperature) }\end{array}$} & \multicolumn{2}{|c|}{$\begin{array}{c}\text { Long-term stability (2 weeks, } \\
\left.-20{ }^{\circ} \mathrm{C}\right)\end{array}$} & \multicolumn{2}{|c|}{ Freeze-thaw stability ( 3 cycles) } \\
\hline & $\begin{array}{l}\text { Recovery (\%) } \\
(\text { mean } \pm \text { SD) }\end{array}$ & $\mathrm{RSD}(\%)$ & $\begin{array}{l}\text { Recovery }(\%) \\
(\text { mean } \pm \mathrm{SD})\end{array}$ & $\operatorname{RSD}(\%)$ & $\begin{array}{l}\text { Recovery }(\%) \\
(\text { mean } \pm \text { SD })\end{array}$ & $\operatorname{RSD}(\%)$ \\
\hline 10 & $92.86 \pm 0.11$ & 0.12 & $112.29 \pm 0.09$ & 0.08 & $100.84 \pm 0.38$ & 0.37 \\
\hline 100 & $110.94 \pm 0.15$ & 0.14 & $102.99 \pm 0.04$ & 0.04 & $105.03 \pm 0.37$ & 0.35 \\
\hline
\end{tabular}

The robustness of the method was evaluated after introducing small deliberate changes in chromatographic conditions, the recovery (\%) was compared to optimum conditions and the system-suitability parameters such as retention time, plate number, tailing factor and resolution were calculated. Recovery (\% ) values were in the range of $98-105 \%$ (Table 7) and no significant change was observed in retention times and system-suitability parameters, indicating the robustness of the method.

Table 7. Robustness of the developed method

\begin{tabular}{|c|c|c|c|c|c|}
\hline Parameter & $\begin{array}{l}\text { Recovery }(\%) \\
(\text { mean } \pm \text { SD) }\end{array}$ & $\begin{array}{l}\text { Retention time } \\
\quad(\min )\end{array}$ & $\begin{array}{c}\text { Theoretical plate } \\
\text { number }\end{array}$ & Tailing factor & Resolution \\
\hline \multicolumn{6}{|c|}{$\mathrm{pH}$ value of mobile phase } \\
\hline 2.9 & $100.26 \pm 0.44$ & $4.692 \pm 0.000$ & $12298 \pm 93.79$ & $1.19 \pm 0.01$ & $7.52 \pm 0.02$ \\
\hline 3.1 & $101.55 \pm 0.76$ & $4.670 \pm 0.002$ & $11778 \pm 120.21$ & $1.21 \pm 0.01$ & $7.26 \pm 0.03$ \\
\hline \multicolumn{6}{|c|}{ Percentage of organic phase (\%) } \\
\hline 38 & $99.09 \pm 0.54$ & $5.783 \pm 0.003$ & $12349 \pm 7.94$ & $1.18 \pm 0.01$ & $10.07 \pm 0.01$ \\
\hline \multicolumn{6}{|c|}{ Buffer concentration (mM) } \\
\hline 18 & $99.77 \pm 0.10$ & $4.729 \pm 0.002$ & $12309 \pm 50.48$ & $1.19 \pm 0.01$ & $7.73 \pm 0.02$ \\
\hline 22 & $100.00 \pm 0.11$ & $4.608 \pm 0.002$ & $12204 \pm 44.98$ & $1.19 \pm 0.01$ & $7.06 \pm 0.01$ \\
\hline \multicolumn{6}{|c|}{ Detection wavelength (nm) } \\
\hline
\end{tabular}


Table 7. Robustness of the developed method (continued)

\begin{tabular}{|l|c|c|c|c|c|}
\hline Flow rate $\left(\mathrm{mL} \mathrm{min}{ }^{-1}\right)$ & & & & & \\
\hline 0.9 & $99.68 \pm 0.22$ & $5.162 \pm 0.001$ & $12033 \pm 19.86$ & $1.19 \pm 0.01$ & $7.26 \pm 0.01$ \\
\hline 1.1 & $100.33 \pm 0.14$ & $4.257 \pm 0.001$ & $10858 \pm 6.24$ & $1.20 \pm 0.01$ & $6.96 \pm 0.01$ \\
\hline HSA concentration $(\mathrm{mM})$ & & & & & \\
\hline 9 & $100.13 \pm 0.35$ & $4.768 \pm 0.003$ & $11597 \pm 28.50$ & $1.19 \pm 0.01$ & $7.74 \pm 0.01$ \\
\hline 11 & $99.96 \pm 0.20$ & $4.526 \pm 0.003$ & $11559 \pm 32.87$ & $1.20 \pm 0.01$ & $6.40 \pm 0.02$ \\
\hline
\end{tabular}

Application of the Method to ASE Tablets

The developed method was applied for the analysis of ASE in its sublingual tablets. ASE content of a sublingual tablet was found as $10.42 \pm 0.06 \mathrm{mg}$ (mean \pm standard deviation, $\mathrm{n}=8)$. RSD (\%) and recovery (\%) values were $0.55 \%$ and $104.18 \%$, respectively; these values are within the limits recommended in USP 22 .

\section{CONCLUSIONS}

This ion-pair chromatography method is a rapid and simple way for the determination of ASE in pharmaceutical dosage forms. It is useful for the analysis at low concentrations and it allows the determination of ASE in a wide concentration range. It is an inexpensive stability indicating method and the HPLC system used can be found in most of the analysis laboratories. The proposed method was fully validated and applied to tablet analysis successfully. As a result, the developed method can be proposed for use in routine analysis laboratories and quality control purposes.

\section{ACKNOWLEDGEMENTS}

This article was derived from the MSc thesis of Sakine Atila Karaca ${ }^{25}$. The authors appreciate Research Council of Anadolu University for the support of the Project (Project No: 1302S023).

\section{REFERENCES}

1. R. Vardanyan, V. Hruby, Antipsychotics (Neuroleptics). Synthesis of essential drugs, Elsevier, Amsterdam, 2006.

2. D. Bishara, D. Taylor, Drugs. 68, 2269, (2008)

3. B. A. Ellenbroek, Neuropharmacology. 62, 1371, (2012)

4. L. Citrome, Expert Opin Drug Saf. 13, 803, (2014)

5. Saphris (asenapine) sublingual tablets, FDA drug approval package. http://www.accessdata.fda.gov/drugsatfda docs/nda/2009/022117s000 ChemR.pdf (accessed Feb 11, 2016).

6. J. M. Gonzalez, P. M. Thompson, T. A. Moore, Patient Prefer Adher. 5, 333, (2011)

7. L. Citrome, Expert Opin Drug Metab Toxicol. 10, 893, (2014)

8. L. Kovatsi, A. Titopoulou, A. Tsakalof, V. Samanidou, J Liq Chrom Relat Tech. 38, 1666, (2015)

9. T. de Boer, E. Meulman, H. Meijering, J. Wieling, P. Dogterom, H. Lass, Biomed Chromatogr. 26, 156, (2012)

10. T. de Boer, E. Meulman, H. Meijering, J. Wieling, P. Dogterom, H. Lass, Biomed Chromatogr. 26, 1461, (2012)

11. N. Ansermot, M. Brawand-Amey, A. Kottelat, C. B. Eap, J Chromatogr A. 1292, 160, (2013)

12. A. V. B. Reddy, N. Venugopal, G. Madhavi, J Pharm Anal. 3, 394, (2013)

13. L. Patteet, K. E. Maudens, B. Sabbe, M. Morrens, M. De Doncker, H. Neels, Clin Chim Acta. 429, 51, (2014)

14. C. Sempio, L. Morini, C. Vignali, A. Groppi, J Chromatogr B Analyt Technol Biomed Life Sci. 970, 1, (2014)

15. C. Miller, O. Pleitez, D. Anderson, D. Mertens-Maxham, N. Wade, J Anal Toxicol. 37, 559, (2013)

16. K. Aarelly, M. K. Thimmaraju, N. Raghunandan, J App Pharm Sci. 2, 141, (2012)

17. O. A. Halima, T. P. Aneesh, R. Ghosh, N. R. Thomas, Der pharma chem. 4, 644, (2012)

18. T. R. Parthasarathi, T. S. Srinivas, M. V. Sri, S. S. Ram, M. M. Basha, P. Rajesh, Int J Pharm Bio Sci. 3, 360, (2012)

19. U. K. Chhalotiya, K. K. Bhatt, D. A. Shah, J. R. Patel, ISci. Pharm. 80, 407,
(2012)

20. R. B. Patel, N. S Naregalkar, M. R. Patel, J Liq Chrom Relat Tech., 38, $1731,(2015)$

21. ICH, Harmonized Tripartite Guideline, Q2 (R1): Validation of Analytical Procedures: Text and Methodology, (2005).

22. The United States Pharmacopeia 29, Easton, (2006).

23. Center for Drug Evaluation and Research, U.S. Food and Drug Administration. Reviewer guidance, Validation of chromatographic methods, FDA, Rockville, MD, (1994).

24. G. A. Shabir, J Chromatogr A. 987, 57, (2003)

25. S. Atila Karaca, MSc Thesis, Determination and Validation of Asenapine in Pharmaceutical Dosage Forms by a Stability Indicating HPLC Method, Anadolu University, (2016). 